Original Research

\title{
Analisis Hukum terhadap Anak yang Sudah Kawin sebagai Subyek yang Berhadapan dengan Hukum (Studi Kasus Putusan Pengadilan Negeri Sampit Nomor: 03/Pid.Sus Anak/2015/PN.Spt)
}

\author{
Nanang Ibrahim Soleh ${ }^{1,}$, Heriamariaty $^{2}$, Thea Farina ${ }^{2}$, Nor Asriadi ${ }^{3}$ \\ ${ }^{1}$ Kejaksaan Tinggi Jawa Timur, Jalan A. Yani 54-56 Surabaya \\ 2 Fakultas Hukum Universitas Palangka Raya, Jalan H. Timang, Kampus Tunjung Nyaho, Palangka Raya \\ ${ }^{3}$ Kantor Wilayah Kementerian Hukum dan HAM Kalimantan Tengah, Jalan Adonis Samad km 3 Nomor 20 Palangka Raya \\ * Korespondensi: Nanang Ibrahim Soleh (Email: mkamsi1958@gmail.com)
}

\begin{abstract}
Children are gifts and entrusted from God who are given talents and dignity as a whole creature. During their lifetime, children sometimes face legal problems such as narcotics abuse. This becomes complicated while the child has been married and being a subject against the law. The determination the age limit for children is still a debate because several laws and regulations provide different figures. This is, indeed, a crucial matter because it will affect legal consequence to the children, especially for those who deal with narcotics crime. Based on this point of departure, the authors examine Sampit District Court Decision Number: 03/Pid.SusAnak/2015/PN.Spt regarding narcotics abuse by a married child.
\end{abstract}

\section{Keywords}

Child married, subject dealing with the law, court verdict

\section{PENDAhuluan}

Anak merupakan karunia dan titipan dari Tuhan yang diberikan talenta, anugerah, harkat dan maratabat sebagai mahkluk ciptaan Tuhan seutuhnya, yang sepatutnya dihormati dan dijaga karena anak diberikan hak-haknya yang melekat tanpa harus anak itu meminta. Anak merupakan cikal bakal sumber daya manusia yang nantinya sangat berpengaruh kepada pembangunan dan anak merupakan subyek hukum yang harus dilindungi karena oleh karenanya wajib diberikan perlindungan hukum.

Pembangunan sumber daya manusia menegaskan bahwa pertanggungjawaban dari semua lapisan masyarakat dimulai dari keluarga, masyarakat sampai Negara adalah wajib dilaksanakan secara bekelanjutan demi melindungi dan menjaga harkat dan martabat seorang anak. Semua upaya tersebut dilaksanakan dengan menjunjung tinggi terjamin tumbuh kembang anak, baik fisik, psikis, spiritual, maupun sosial, sehingga dapat mewujudkan harapan yang terbaik bagi anak sebagai cikal bakal ujung tombak negara yang memilki potensi, unggul mempunyai jiwa patriotisme dalam mengamalkan dan mempedomani nilai-nilai moral yang terkandung di dalam
Pancasila. Anak-anak juga membutuhkan kemampuan spiritual yang kokoh, dalam rangka mewujudkan harapan bangsa ke depan untuk menjaga kesatuan dan persatuan bangsa dan negara (Al Bukhori, 2009).

Prinsip-prinsip tersebut juga terdapat dalam ketentuan Undang-Undang Nomor 17 Tahun 2016 tentang Penetapan Peraturan Pemerintah Pengganti UndangUndang Nomor 1 Tahun 2016 tentang Perubahan Kedua Atas Undang-Undang Nomor 23 Tahun 2002 tentang Perlindungan Anak menjadi Undang-Undang yang disahkan oleh Presiden bersama DPR dengan tujuan menjunjung tinggi hak-hak anak di Indonesia. Bentuk perlindungan negara Indonesia dalam menjaga, melindungi dan menghormati hak-hak sebenarnya sudah diterapkan dari tahun 1979 saat membentuk UndangUndang Nomor 4 Tahun 1979 tentang Kesejahteraan Anak. Akan tetapi faktanya masih banyak anak yang tidak mendapatkan kehidupan terbaik seperti yang diharapkan.

Dari tabulasi bank data kasus perlindungan anak yang dimiliki Komisi Perlindungan Anak Indonesia (selanjutnya disingkat KPAl), dari tahun 2011 hingga tahun 2016 terdapat sebanyak 7.132 Anak Berhadapan dengan Hukum (selanjutnya disingkat $A B H$ ). Terpampang dari tahun 2011 
hinga tahun 2014, data anak yang tersangkut masalah hukum baik sebagai pelaku, korban maupun saksi terus menanjak. Namun pada tahun 2015 dan 2016, angkanya menurun. Jenis $A B H$ ini dibagi tiga yakni $A B H$ sebagai pelaku, $A B H$ sebagai korban, dam $A B H$ sebagai saksi. Mirisnya $A B H$ sebagai korban lebih banyak dari dua jenis $A B H$ yang lain. Rinciannya, $A B H$ sebagai korban sebanyak 4.086 pengaduan, $\mathrm{ABH}$ sebagai pelaku sebanyak 3.010 dan $\mathrm{ABH}$ sebagai saksi 36 laporan. Sedangkan data terakhir terhadap data Pengaduan KPAl untuk $A B H$ pada Tahun 2019 sebanyak 555 kasus (Hukum Online, 2016).

Dari data di atas, dapat disimpulkan bahwa selama tahun 2019, kasus ABH semakin tahun semakin meningkat. Untuk penanganan kasus $\mathrm{ABH}$ dengan hukum KPAI banyak berkoordinasi dengan aparat penegak hukum (selanjutnya disingkat $\mathrm{APH}$ ) dan untuk penanganannya lebih banyak diselesaikan secara pidana sesuai dengan pelaksanaan Undang-Undang Nomor 11 Tahun 2012 tentang Sistem Peradilan Pidana Anak (Hukum Online, 2016).

Berdasarkan data Kementerian Pemberdayaan Perempuan dan Perlindungan Anak Republik Indonesia dan Institute for Criminal Justice Reform -sebuah lembaga kajian independen yang memfokuskan diri pada reformasi hukum pidana, reformasi sistem peradilan pidana dan reformasi hukum pada umumnya di Indonesia- pada tahun 2016/2017 ditemukan sebanyak 21 anak yang terjerat kasus narkotika dalam praktik persidangan. Dari 21 kasus tersebut, 11 diantaranya, Hakim menjatuhi putusan berupa pidana penjara sebanyak $37 \%$, kemudian sanksi berupa pidana pelatihan kerja sebanyak $18 \%$, yang dipulangkan kembali ke orang tua atau wali sebanyak $18 \%$, sedangkan upaya rehabilitasi sosial sebanyak $18 \%$ dan hanya $9 \%$ atau satu kasus dimana anak direhabilitasi (Anggara dan Napitulu, 2016). Berdasarkan data tersebut dominasi hukuman penjara masih sangat dominan dibandingkan rehabilitasi.

Perlu diperhatikan juga bahwa kasus-kasus $\mathrm{ABH}$ yang masuk ke dalam proses hukum wajib selalu mengedapankan dan memperhatikan prinsip yaitu menjunjung tinggi kepentingan yang terbaik bagi anak, serta upaya pembalasan bagi anak melalu hukuman pidana penjara adalah langka terakhir (Ultimum Remedium) dengan tetap tidak mengindahkan harkat dan martabat seorang anak.

Adapun kasus yang menjadi perhatian peneliti adalah kasus tindak pidana narkotika yang ditangani oleh Penyidik Polres Sampit yang diproses oleh Kejaksaan Negeri Sampit dan yang telah disidangkan serta divonis oleh Pengadilan Negeri Sampit, dimana dalam kasus tersebut yang menjadi pelaku tindak pidana narkotika seorang perempuan berumur 15 (lima belas) tahun yang bernama WATI SARMILA ALS JESIKA MILA BINTI ARDALIASNSYAH, anak dibawah umur dengan status sudah kawin yang berhadapan dengan hukum dalam kasus Tindak Pidana Narkotika dan dijatuhi pidana selama 1 (satu) bulan 15 (lima belas) hari.

Berdasarkan Petikan Putusan Pidana Nomor 03/Pid.Sus-
Anak/2015/PN.Spt, Pengadilan Negeri Sampit telah menjatuhkan putusan perkara Anak pada Pengadilan Tingkat Pertama dengan acara pemeriksaan khusus an. WATI SARMILA ALS JESIKA MILA ALS MILA BINTI ARDALIANSYAH, menyatakan telah terbukti secara sah dan meyakinkan bersalah melakukan tindak pidana "percobaan Menyalahgunakan Narkotika Golonngan I dan menjatuhkan pidana oleh karena itu terhadap diri anak tersebut dengan Pidana Penjara selama 1 (satu) tahun 15 (lima belas) hari.

Adapun dasar hukum yang dikenakan adalah memperhatikan Pasal 53 ayat (1) KHUP jo. Pasal 127 ayat (1) huruf a Undang-Undang Nomor 35 Tahun 2009 tentang Narkotika, Pasal 71 ayat (1) huruf e Undang-Undang Nomor 11 Tahun 2012 tentang Sistem Peradilan Pidana Anak dan pasal pasal lain dalam Undang-Undang Nomor 8 Tahun 1981 tentang Kitab Undang-Undang Pidana serta peraturan perundang-undangan lainnya yang berkaitan dengan perkara ini.

Contoh kasus di atas merupakan fakta yang telah diterapkan dalam peradilan di Indonesia pada umumnya dan di Kabupaten Kotawaringin Timur pada khususnya. Dalam hal si anak dapat membuktikan bahwa dirinya adalah sebagai korban penyalahgunaan narkotika, maka anak tersebut wajib menjalani rehabilitasi medis atau rehabilitasi sosial, hal ini sesuai dengan ketentuan bunyi Pasal 127 ayat (3) Undang-Undang Nomor 35 Tahun 2009 tentang Narkotika, yang menyebutkan bahwa:

"Dalam hal Penyalahguna sebagaimana dimaksud pada ayat (1) dapat dibuktikan atau terbukti sebagai korban penyalahgunaan narkotika, Penyalah Guna tersebut wajib menjalani rehabilitasi medis dan rehabilitasi sosial".

Namun apabila ia tidak dapat membuktikan namun terbukti sebagai penyalahguna narkotika golongan I, maka anak tersebut diancam dengan pidana penjara paling lama 4 (empat) tahun (namun $1 / 2$ dari maksimum ancaman pidana penjara bagi orang dewasa) sebagaimana menurut Pasal 127 ayat (1) huruf a Undang-Undang Narkotika (Pramesti, 2016). Meskipun demikian, seperti disebutkan diatas, terdapat upaya diversi yang bias dijalani oleh anak, yaitu penyelesaian perkara anak untuk dialihkan dari proses peradilan pidana ke luar peradilan pidana. Oleh karena itu sepatutnya para penegak hukum perlu melaksanakan upaya diversi sebelum melaksanakan proses peradilan anak tersebut melalui proses peradilan pidana (Pramesti, 2016).

Sebagai perbandingan hukum di atas, Penulis mencoba membandingkan terhadap Putusan Pengadilan Negeri Sampang Nomor Putusan 125/Pid.B/2015/PN Spg dalam perkara pidana dengan acara pemeriksaan biasa tingkat pertama an. RIDWAN BIN MUJAHIT terdapat adanya tuntutan penuntut umum yang menyatakan:

1. Terdakwa Ridwan Bin Mujahit telah terbukti secara sah dan menyakinkan bersalah melakukan tindak pidana 
"pencurian" dan "melakukan kekerasan terhadap anak" sebagaimana yang termuat di Pasal 362 KUHP dalam surat dakwaan kesatu dan Pasal 80 UU Nomor 35 Tahun 2014 tentang Perubahan atas UU Nomor 23 Tahun 2002 tentang Perlindungan Anak dalam surat dakwaan kedua;

2. Menjatuhkan pidana terhadap terdakwa Ridwan Bin Mujahit dengan pidana penjara selama 4 (empat) tahun dikurangi selama terdakwa berada dalam tahanan dengan perintah agar terdakwa tetap ditahan;

3. Surat bukti pembayaran pajak kendaran bermotor nomor 001655131 jenis motor matic bukti Honda beatwarna putih kombinasi biru tahun 2014 No. Pol L5878-NX Noka MHIJFM211EK372548 Mesin JFM2E1367493 atas nama Marfuah dikembalikan kepada pemiliknya yaitu saksi Ernawati;

4. Menetapkan agar terdakwa membayar biaya perkara sebesar Rp.5000,- (lima ribu rupiah).

Jika difokuskan kepada aspek perlindungan terhadap seorang yang masih tergolong sebagai anak dalam tuntutan dimaksud maka tuntutan Jaksa tidak dibenarkan oleh hakim berdasarkan beberapa pertimbangan. Dalam kasus di atas terdapat anak yang berhadapan dengan hukum yaitu Ernawati yang merupakan korban berusia 15 tahun, namun diusianya yang masih tergolong anak, ia pernah kawin secara negara kemudian cerai dan sekarang korban berusia 17 tahun dan kawin secara agama/nikah siri dengan terdakwa. Berdasarkan berita acara dan saksi di Pengadilan Negeri Sampang terdapat kekerasan terhadap korban yang dilakukan oleh terdakwa.

Terkait kasus di atas, terdapat adanya pertimbangan bahwa:

"Menimbang bahwa pada saat terjadi kekerasan tersebut menurut pengakuan korban Ernawati yang dikuatkan oleh keterangan saksi Tirah dan yang lainnya keterangan mana tidak dibantah oleh terdakwa bahwa korban Ernawati berusia 17 tahun dan setelah Majelis Hakim mempelajari Berkas acara penyidik maka ditemukan dalam ijazah Sekolah dasar atas nama Ernawati, tanggal 16 juni 2012 yang menerangkan bahwa korban Ernawati lahir pada tanggal 17 Agustus 1998, usia mana jelas masih dibawah usia 18 (delapan belas) tahun".

dan

"Menimbang, bahwa akan tetapi berdasarkan keterangan Korban Ernawati yang dikuatkan oleh keterangan Saksi Tirah, Saksi Ach. Fauzi, Saksi Moh. Selket dan Terdakwa menerangkan Korban Ernawati pada saat berumur 15 tahun pernah menikah secara Negara kemudian pernikahan tersebut telah bercerai dan setelah Majelis hakim mempelajari bukti surat yang diajukan oleh Saksi Ach. Fauzi yaitu Kutipan Akta Nikah Nomor 0536/116/VI/2013 yang pada pokoknya menerangkan telah terjadi pernikahan antara Korban Ernawati dengan Hasanuddin yang mana kemudian pernikahan Korban Ernawati dan Hasanuddin tersebut telah bercerai sesuai dengan Akta Cerai Nomor 132/AC/2014/PA.Sampang, kemudian Korban Ernawati kembali menikah dengan Terdakwa secara agama/nikah siri dan sekarang Korban Ernawati telah bercerai dengan Terdakwa".

Berdasarkan hal tersebut baik fakta-fakta yang dijelaskan di atas maka Majelis Hakim berpandangan yaitu Korban Ernawati tidak tergolong dalam usia anak, karena meskipun belum berusia 18 tahun tetapi ia telah menikah/ kawin. Adapun hasil putusan pengadilan menyatakan bahwa membebaskan terdakwa Ridwan Bin Mujahit oleh karena itu dari Dakwaan kedua yaitu melakukan kekerasan terhadap anak dan menyatakan terdakwa Ridwan Bin Mujahit tersebut di atas, terbukti secara sah dan menyakinkan melakukan tindak pidana "pencurian" sebagaimana dalam Dakwaan kesatu.

Berdasarkan perbandingan kedua hukum di atas, masalah penanganan $\mathrm{ABH}$ adalah kategori anak yang ditentukan berbeda beda dalam Peraturan Perundangundangan di Indonesia. Bahkan di antara para hakim pun belum ada keseragaman dalam menerapkan batasan usia dewasa, ada yang berpendapat bahwa batasan usia anak yaitu 21 tahun, namun ada pula yang berpendapat yaitu batasan usia anak adalah dibawah 18 tahun, bahkan 17 tahun.

Terkait studi kasus yang diangkat oleh Penulis yaitu anak yang sudah kawin sebagai subyek yang terjerat hukum dalam kasus narkotika yang terjadi di Sampit, bahwa selain permasalahan berbeda-bedanya pertimbangan hakim dalam menentukan batasan usia anak, disisi lain kasus yang menjerat anak tersebut adalah penyalahgunaan narkotika. Seorang anak yang menjadi pelaku penyalahgunaan narkotika pada anak sangat memprihatinkan mengingat mereka harus berhadapan dengan hukum karena melakukan tindak pidana dan harus mempertanggungjawabkan perbuatan yang telah mereka lakukan. Seorang anak yang menjadi pelaku penyalahgunaan narkoba juga akan diproses melalui Peraturan Perundang-undangan yang sama dengan pelaku dewasa, hanya saja untuk pelaku anak proses peradilannya berbeda dengan pelaku orang dewasa. Oleh karena permasalahan mengenai batasan usia anak yang terjerat hukum namun status anak tersebut sudah kawin akan sangat diperlukan karena penentuan batas usia anak sangat menjadi penting, sebab akan berdampak pada akibat hukum yang harus dijalani oleh seorang anak yang sudah kawin.

Permasalahan yang ingin dibahas dalam kajian ini yaitu mengenai pengaturan anak yang sudah kawin sebagai subyek yang berhadapan dengan hukum serta hal-hal apa yang menjadi pertimbangan hakim dalam menjatuhkan putusan terhadap anak yang sudah kawin sebagai subyek yang berhadapan dengan hukum berdasarkan Putusan Pengadilan Negeri Sampit Nomor:03/Pid.Sus-Anak/2015/ PN.Spt. 
Adapun yang menjadi tujuan dari penulisan ini adalah untuk mengetahui pengaturan anak yang sudah kawin sebagai subyek yang berhadapan dengan hukum berdasarkan Peraturan Perundang-undangan serta untuk mengetahui pertimbangan hakim dalam menjatuhkan putusan terhadap anak yang sudah kawin sebagai subyek yang berhadapan dengan hukum berdasarkan Putusan Pengadilan Negeri Sampit Nomor:03/Pid.Sus-Anak/2015/ PN.Spt. Untuk mendukung penulisan ini metode penelitian yang digunakan adalah yuridis normatif, yaitu penelitian yang dilakukan atau ditujukan pada Peraturan-Peraturan tertulis dan bentuk-bentuk dokumen resmi atau disebut juga dengan data sekunder, berupa bahan-bahan dari buku-buku yang ada hubungannya dengan masalah yang dibahas (Soekanto dan Mamudji, 2014). Berkaitan dengan permasalahan dalam tulisan ini maka pengkajian dilakukan dengan menganalisis Undang-Undang Nomor 23 Tahun 2002 tentang Perlindungan Anak sebagaimana telah diubah beberapa kali terkahir dengan Undang-Undang Nomor 17 Tahun 2016 tentang Penetapan Atas Peraturan Pemerintah Pengganti Undang-Undang Nomor 1 Tahun 2016 tentang Perubahan Kedua Atas Undang-Undang Nomor 23 Tahun 2002 tentang Perlindungan Anak menjadi Undang-Undang, Undang-Undang Nomor 35 Tahun 2009 tentang Narkotika dan Undang-Undang Nomor 11 Tahun 2012 tentang Sistem Peradilan Pidana Anak.

\section{HASIL DAN PEMBAHASAN}

\subsection{Pengaturan Anak yang Sudah Menikah sebagai Subyek sang Berhadapan dengan Hukum}

Dalam perspektif hukum, subyek hukum berarti sebagai orang yang merupakan pemegang hak, dalam hal ini manusia dan badan hukum. Manusia sudah pasti terlahir sebagai subyek hukum menurut ketentuan hukum yang berlaku di Indonesia, dimana masing-masing setiap orang terlahir sebagai subyek hukum yang melekat secara kodrat maupun secara alamiah, tidak terkecuali untuk anak. Anak sudah dapat dikatakan sebagai subyek hukum, sejak dilahirkan sampai dengan meninggal dunia. Bahkan sejak anak mulai tumbuh dan berkembang dalam kandungan pun dapat dikatakan sebagai subyek hukum jika ada sebab akibat atau keperluan yang menghendakinya (Andrianih, 2014).

Oleh karena itu, anak mulai dari dalam kandungan sampai dengan ia dewasa termasuk dalam subyek hukum. Namun permasalahannya adalah batasan usia anak sampai dikatakan dewasa menurut hukum mempunyai ketentuan yang berbeda-beda.

\section{a. Kitab Undang-Undang Hukum Perdata}

Definisi anak yang berangkat dari konsep hukum perdata diawali dari konsep aspek keperdataan yang melekat anak sebagai subjek hukum yang belum seutuhnya terbentuk sempurna. Pasal 330 KUHPerdata memberikan pengertian anak adalah:

"orang belum dewasa yang belum mencapai umur genap 21 (dua puluh satu) tahun dan tidak lebih dahulu telah kawin."

Pengertian ini sama dengan yang disebutkan oleh Undang-Undang Nomor 4 Tahun 1979 tentang Kesejahteraan Anak, dalam Pasal 1 ayat (2) menyebutkan bahwa:

"anak adalah seseorang yang belum mencapai umur 21 (dua puluh satu) tahun dan belum pernah kawin".

Pengertian tentang anak ini diletakkan sama maknanya dengan mereka yang belum dewasa dan seseorang yang belum mencapai usia batas legitimasi hukum sebagai subjek hukum atau layaknya subjek hukum normal yang ditentukan oleh undang-undang perdata (Muljono, 1998).

Dalam keperdataan, anak memiliki peran yang sangat penting, terlebih lagi untuk urusan mengenai hak-hak keperdataan anak. Contonya terkait persoalan bagi atau serah harta warisan, oleh karenanya, anak yang bahkan masih dalam kandungan bahkan lagi meskipun anak itu seorang perempuan sekalipun diumpamakah oleh hukum seperti sudah telah dilahirkan jika keperluan si anak menghendaki sebagaimana yang dimaksudkan oleh Pasal 2 KUHPerdata (Satrio, 1999).

\section{b. Kitab Undang-Undang Hukum Pidana}

Dalam Pasal 45 KUHP, seorang dapat dikatakan untuk boleh dituntu secara pidana yaitu khusus bagi seseorang yang belum berumur 16 tahun. Oleh karenanya dari dasar Pasal 45 KUHPidana batasan umur seseorang anak telah dikatakan dewasa apabila telah mencapai umur 16 tahun. Jika dilihat definisi mengenai anak dari sudut pandang hukum pidana yaitu, apabila seorang anak terjerat dalam perkara pidana hakim boleh mengeluarkan perintah agar anak tersebut dikembalikan pada orang tuanya, atau walinya atau Negara dengan tidak menyatakan atau menjatuhkan hukuman (Prinst, 1997).

\section{c. Undang-Undang Nomor 1 Tahun 1974 tentang Perkawinan \\ Undang-Undang Nomor 1 Tahun 1974 tentang} Perkawinan tidak mengatur secara langsung tolak ukur kapan seseorang digolongkan sebagai anak. Akan tetapi dalam Pasal 6 ayat (2), menyatakan bahwa:

"Untuk melangsungkan perkawinan seorang yang belum mencapai umur 21 (duapuluh satu) tahun harus mendapat izin kedua orang tua."

Selanjutnya dalam Pasal 7 ayat (1) menyatakan bahwa: "Perkawinan hanya diizinkan jika pihak pria sudah mencapai umur 19 (sembilan belas) tahun dan pihak wanita sudah mencapai umur 16 (enam belas) tahun."

Dari pasal-pasal tersebut di atas maka dapatlah 
disimpulkan bahwa anak dalam Undang-Undang Nomor 1 Tahun 1974 tentang Perkawinan adalah mereka yang belum dewasa dan sudah sudah dewasa yaitu 16 (enam belas) tahun untuk perempuan dan 19 (sembilan belas) tahun untuk laki-laki.

\section{d. Undang-Undang Nomor 39 Tahun 1999 tentang Hak Asasi Manusia}

Dalam Undang-Undang ini secara tegas mengakui eksistensi anak. Menurut Undang-Undang HAM yang dikatakan sebagai usia anak yaitu setiap orang yang berumur di bawah 18 tahun dan belum pernah menikah, tidak terkecuali anak yang masih dalam kandungan.

Selanjutnya Pasal 52 ayat (1) mengamanatkan untuk upaya perlindungan bagi anak wajib untuk dilaksanakan oleh elemen masyarakat mulai dari Pemerintah sampai pada orang tua sendiri atau walinya. Sedangkan Pasal 58 ayat (1) memastikan pemberian jaminan kepada anak untuk dapat dukungan dari Pemerintah berupa bentuk perlindungan hukum dari segala macam kekerasan baik fisik maupun mental, mengabaikan, sampai pada bentuk pelecehan seksual.

\section{e. Undang-Undang Nomor 23 Tahun 2002 tentang Perlindungan Anak sebagaimana telah diubah beberapa kali terakhir dengan Undang-Undang Nomor 17 Tahun 2016 tentang Penetapan Peraturan Pemerintah Pengganti Undang-Undang Nomor 1 Tahun 2016 tentang Perubahan Kedua Atas Undang-Undang Nomor 23 Tahun 2002 tentang Perlindungan Anak Menjadi Undang- Undang}

Perlindungan hukum terhadap sangat diperlukan, karena anak merupakan generasi penerus bangsa dan merupakan penerus cita-cita perjuangan bangsa sekaligus modal sumberdaya manusia bagi pembangunan nasional. Sehubungan dengan hal tersebut, Pemerintah telah menerbitkan Peraturan Perundang-undangan yang secara khusus (lex specialis) mengatur mengenai perlindungan anak yaitu Undang-Undang Nomor 23 Tahun 2002 tentang Perlindungan Anak.

Dalam Pasal 1 angka 1 Undang-Undang Perlindungan Anak, menyebutkan bahwa:

"Anak adalah seseorang yang belum berusia 18 (delapan belas) tahun, termasuk anak yang masih dalam kandungan."

Definisi anak dalam Undang-Undang Perlindungan Anak ini berbeda dengan aturan-aturan sebelumnya sebagaimana diuraikan di atas yang mengkategorikan anak yaitu seorang belum berusia sesuai pandangannya dan aturannya masing namun, usia anak akan gugur dengan sendirinya ketika anak tersebut pernah atau sudah kawin, maka ia tidak lagi dapat dikategorikan sebagai anak melainkan seseorang yang telah dewasa dari sebelumnya yang diharuskan mencapai batas umur tertentu.

Perlindungan anak menurut Undang-Undang ini memiliki tujuan dalam rangka menjamin hak anak agar dapat menjalani kehidupannya namun harkat dan martabat tetap dijaga dan dihormati, dan dilindungi dari segala bentuk kekerasan dan diskriminasi, demi mewujudkan bangsa Indonesia yang berkuaitas, berakhlak mulia, dan sejahtera. Sehingga Undang-Undang Perlindungan Anak ini merupakan aturan yang sifatnya khusus sebagai bentuk nyata perlindungan hukum oleh Negara kepada anak.

Dalam hal kasus yang diteliti oleh Penulis mengenai pengaturan kategori batas usia anak yang sudah menikah sebagai subyek yang berhadapan dengan hukum, maka berpedoman pada aturan Undang-Undang Perlindungan Anak ini yang merupakan aturan bersifat khusus (lex specialis), yaitu mengkategorikan usia anak adalah 18 (delapan belas) tahun, tanpa menyebutkan apakah anak tersebut sudah menikah atau belum.

\section{f. Undang-Undang Nomor 11 Tahun 2012 tentang Sistem Peradilan Pidana Anak}

Dalam Undang-Undang ini, Negara memberikan Perlindungan khusus kepada anak yang tersangkut atau terlibat dengan kasus hukum. Terkait dengan kasus yang Penulis teliti, dalam rangka menjaga harkat dan martabat anak, maka anak berhak mendapatkan pelindungan khusus, terutama pelindungan hukum dalam sistem peradilan pidana. Berdasarkan Pasal 1 angka 2 UndangUndang Sistem Peradilan Pidana Anak, menyatakan bahwa:

"Anak yang Berhadapan dengan Hukum adalah anak yang berkonflik dengan hukum, anak yang menjadi korban tindak pidana, dan anak yang menjadi saksi tindak pidana."

Selanjutnya dalam Pasal 1 angka 3 Undang-Undang Nomor 11 Tahun 2012 tentang Sistem Peradilan Pidana Anak, menyatakan bahwa:

"Anak yang Berkonflik dengan Hukum yang selanjutnya disebut Anak adalah anak yang telah berumur 12 (dua belas) tahun, tetapi belum berumur 18 (delapan belas) tahun yang diduga melakukan tindak pidana."

Kemudian dalam Pasal 1 angka 6 Undang-Undang Nomor 11 Tahun 2012 tentang Sistem Peradilan Pidana Anak, menyatakan bahwa:

"Keadilan Restoratif adalah penyelesaian perkara tindak pidana dengan melibatkan pelaku, korban, keluarga pelaku/korban, dan pihak lain yang terkait untuk bersama-sama mencari penyelesaian yang adil dengan menekankan pemulihan kembali pada keadaan semula, dan bukan pembalasan."

Beberapa ketentuan dalam Pasal UU SPPA diatas, menyebutkan bahwa anak sebagai suyek yang tersangkut paut dengan hukum itu, bisa anak sebagai pelaku, korban dan/atau saksi, tergantung perbuatan atau tindakan anak tersebut dalam sebuah kasus. 
Secara normatif batasan kategori usia anak, terlepas sebagai pelaku, korban ataupun saksi, dalam UU SPPA tersebut jelas bahwa batasan usia dikatakan sebagai anak adalah yang belum mencapai usia 18 tahun, tanpa terkecuali apakah statusnya sudah kawin atau belum.

Pengaturan batasan usia anak dalam UU SPPA ini juga serupa dengan yang diatur dalam Undang-Undang Perlindungan Anak yang merupakan aturan paling baru yang mengatur ketentuan mengenai definisi anak, kedua Undang-Undang ini sepakat membatasi usia seorang sebagai anak ketika anak tersebut belum mencapai usia 18 tahun, tanpa norma apakah sudah kawin atau belum. Dengan kata lain, bahwa sepanjang anak tersebut belum mencapai usia 18 tahun, ia tetap dianggap sebagai anak.

Berdasarkan uraian dari beberapa ketentuan diatas, kategori batas usia anak atau usia dewasa berbeda-beda antara satu Undang-Undang dengan Undang-Undang lainnya, ada yang menyebutkan 16 tahun, 17 tahun, 18 tahun bahkan 21 tahun. Belum ada satu pemahaman dan satu rumusan yang menyebutkan secara jelas batas usia anak dan dewasa.

Untuk menegaskan masalah kategori usia anak ini, khususnya frasa pengaturan pernah kawin, perlu dipahami bahwa meskipun batas usia anak hampir serupa dengan batas usia belum dewasa, jika diperhatikan lebih seksama lagi keduanya mempunyai maksud pengaturan yang tujuannya berbeda pula.

Beda substansi diantara kedua istilah tersebut harus ditelisik secara hati-hati karena mengandung arti dan konsekuensi akibat hukum yang berbeda pula dalam prakteknya. Uraian mengenai letak perbedaan istilah anak dan belum dewasa yaitu penggunaan diksi Anak dipakai untuk dalam upaya pembahasan mengenai perlindungan hukum dalam konteks hukum publik termasuk hukum pidana, sedangkan belum dewasa dipakai saat akan membahas persoalan yang bersinggungan dengan masalah keperdataan dalam lingkup hukum kebendaan dan perikatan karena undang-undang;

Konsekuensi logis dari perbedaan istilah-istilah tersebut antara lain adalah dalam topik pembahasan mengenai anak terkait perkara pidana anak, aturannya tidak mempermasalahkan status anak tersebut pernah menikah/kawin atau belum menikah/kawin. Sepanjang seseorang itu belum berusia 18 tahun, maka yang bersangkutan harus dianggap tetap sebagai Anak. Sebaliknya saat membahas masalah cakapnya seseorang dalam perbuatan dan tindakan dari sisi perdata, meskipun orang tersebut belum mencapai usia 18 tahun, namun apabila telah lebih dulu menikah/kawin, maka dianggap dan diakui kedewasaannya dalam bertindak.

Oleh karenanya dengan untuk menegaskan hak tersebut, perlu adanya upaya penegasian aturan yang membedakan frame atau bingkai hukum mengenai masalah istilah anak atau belum dewasa yang tujuan penyelesaiannya pun berbeda, ada yang bermuara pada ketentuan pidana ada pula yang bermuara pada masalah keperdataan, atau sifatnya kasuistis, sehingga perlu dilakukan terobosan melalui pembaruan hukum yang mengatur terkait masalah anak untuk kepentingan hukum publik maupun belum dewasa dalam lingkup hukum privat.

Untuk mengatasi permasalahan disharmoni tersebut, menurut Manan (2004) dapat digunakan asas-asas hukum, diantaranya:

a. Lex specialis derogat legi generalis

Aturan yang khusus mengesampingkan aturan hukum yang umum. Salah satu prinsip penggunaan asas ini yaitu:

1) aturan hukum yang sifatnya umum masih tetap berlaku, kecuali terdapat aturan khusus yang mengaturnya.

2) Peraturan tersebut harus sejajar atau hierarkinya sama misalnya undang-undang dengan undangundang.

b. Asas lex posterior derogat legi priori.

Aturan yang terbaru mengesampingkan aturan yang lama. Penggunaan asas ini harus mempedomani prinsip yaitu aturannya harus yang sama atau sejajar atau bisa hirarkinya lebih tinggi dari aturan hukum sebelumnya, selain itu hukum baru dan lama mengatur substansi dan ruang lingkup yang serupa (Manan, 2004).

Selain itu, berkaitan dengan prinsip atau kepatutan hukum, menurut pendapat Purwacaraka sebagaimana dikutip oleh Yuliandri (2009), bahwa agar suatu peraturan perundang-undangan dapat berlaku secara baik dan sesuai harapan, jika substansinya memperhatikan asasasas tersebut, salah satunya, Lex Specialis Derogat Lex Generalis yaitu undang-undang yang khusus mengenyampingkan undang-undang yang bersifat umum.

Berdasarkan hal tersebut, untuk menyelesaikan disharmoni antara Peraturan Perundang-undangan terkait kasus pidana oleh anak, maka diperlukan asas Lex Specialis Derogat Lex Generalis, guna menyelesaikan pertentangan antara Peraturan dimaksud. Dalam hal kasus yang diangkat oleh Penulis seharusnya mengacu pada Undang-Undang Nomor 23 Tahun 2002 tentang Perlindungan Anak dan Undang-Undang Nomor 11 Tahun 2012 tentang Sistem Peradilan Pidana Anak, yang menyatakan bahwa anak adalah seseorang yang belum berusia 18 tahun, tanpa terkecuali apakah sudah kawin atau belum.

\subsection{Pertimbangan Hakim Dalam Menjatuhkan Putusan Terhadap Anak Yang Sudah Menikah Sebagai Subyek Yang Berhadapan Dengan Hukum Berdasarkan Putusan Pengadilan Negeri Sampit Nomor: 03/Pid.Sus-Anak/2015/PN.Spt}

Terkait dengan kasus yang Penulis teliti, yaitu anak yang berurusan dengan narkotika yaitu kasus yang pernah ditangani oleh Penyidik Polres Sampit yang diproses oleh Kejaksaan Negeri Sampit dan yang telah disidangkan serta divonis oleh Pengadilan Negeri Sampit. Dimana dalam kasus tersebut yang menjadi pelaku yaitu seorang perempuan berumur 15 (lima belas) Tahun yang bernama WATI SARMILA ALS JESIKA MILA BINTI ARDALIASNSYAH, 
anak dibawah umur dengan status sudah kawin yang terjerat kasus hukum yaitu kasus narkotika dan dijatuhi pidana selama 1 (satu) bulan 15 (lima belas) hari.

Berdasarkan Berita Acara Pemeriksaan yang dilakukan oleh Kepolisian Resort Kotawaringin Timur, dapat diketahui identitas tersangka yaitu WATI SARMILA Als JESIKA MILA Als MILA Binti ARDALIANSYAH, umur 15 tahun, dilahirkan di Sampit (Kabupaten Kotawaringin Timur), Agama Islam, Jenis kelamin Perempuan, Suku/ bangsa Dayak/Indonesia, Pendidikan Terakhir MTS Kelas II (Tidak Tamat) tidak melanjutkan lagi sekolah karena tidak ada biaya kemudian menikah pada tahun 2014 dengan seorang laki-laki yang bernama SUHERMAN, Alamat JL. Lesa RT. 10 RW. 02 Kelurahan Parenggean Kecamatan Parenggean Kabupaten Kotawaringin Timur Kalimantan Tengah dan/atau Desa Pelangsian Gg Cempaka Kecamatan MB Ketapang Sampit Kabupaten Kotawaringin Timur Kalimantan Tengah.

Kronologis kejadian saat itu yaitu pada hari Jumat tanggal 28 Februari 2015 Pukul 23.30 WIB, WATI bermain kerumah saudara NURUL RAHMAN Als NURUL Bin KELU Als USMAN, kemudian WATI dipanggil saudara NURUL RAHMAN Als NURUL Bin KELU Als USMAN masuk kedalam kamar dan disuruh duduk kemudian saudara NURUL RAHMAN Als NURUL Bin KELU Als USMAN menyiapkan alat untuk menghisap sabu dan WATI duduk disampingnya dan setelah selesai menyiapkan peralatan untuk memakai sabu kemudian saudara NURUL RAHMAN Als NURUL Bin KELU Als USMAN mengambil sabu dari dalam kantong sebelah kanan dan kemudian memasukan kedalam pipet kaca yang sudah tersedia dan setelah itu saudara NURUL RAHMAN Als NURUL Bin KELU Als USMAN menyuruh WATI memegang sedotan yang terhubung dari bong dan setelah itu saudara NURUL RAHMAN Als NURUL Bin KELU Als USMAN membakar pipet kaca yang didalamnya berisi sabu tersebut dan setelah itu datang petugas Kepolisian melakukan penggeledahan dan ditemukan barang berupa 5 (lima) bungkus plastik kecil yang berisi butiran Kristal warna bening yang diduga Narkotika jenis sabu yang disimpan dalam sebuah kotak plastik warna pink yang berada dalam lipatan celana warna biru merk celcius yang dipakai saudara NURUL RAHMAN Als NURUL Bin KELU Als USMAN dan juga ditemukan barang berupa 1 (satu) buah pipet kaca yang berisi butiran Kristal warna putih, 1 (satu) buah bong yang terbuat dari botol kaca, 1(satu) buah kompor yang terbuat dari korek api gas lengkap dengan sumbunya, 1 (satu) buah timbangan digital merk CE. Motif pelaku menggunakan narkotika golongan I jenis sabu berdasarkan BAP oleh Kepolisian adalah diajak teman untuk mencoba sabu sehingga pelaku mau memakai sabu bersama dengan saudara NURUL RAHMAN Als NURUL Bin KELU Als USMAN tersebut.

Berdasarkan Petikan Putusan Pidana Nomor 03/Pid.Sus -Anak/2015/PN.Spt, Pengadilan Negeri Sampit telah menjatuhkan putusan perkara Anak pada Pengadilan Tingkat Pertama dengan acara pemeriksaan khusus an. WATI SARMILA ALS JESIKA MILA ALS MILA BINTI
ARDALIANSYAH, menyatakan bahwa:

1. Anak yang bernama WATI SARMILA ALS JESIKA MILA ALS MILA BINTI ARDALIANSYAH telah terbukti bersalah melakukan tindak pidana "percobaan menyalahgunakan narkotika golongan l; dan

2. Menjatuhkan pidana oleh karena itu terhadap diri anak tersebut dengan Pidana Penjara selama 1 (satu) tahun 15 (lima belas) hari.

Berdasarkan dasar hukum tersebut, pertimbangan hakim dalam menjatuhkan Putusan Pidana Nomor 03/ Pid.Sus-Anak/2015/PN.Spt, atas nama WATI SARMILA ALS JESIKA MILA ALS MILA BINTI ARDALIANSYAH, yaitu:

1. Pelaku masih dikategorikan sebagai anak oleh hakim meskipun sudah menikah sehingga hakim menggunakan pertimbangan berdasarkan UndangUndang Nomor 11 Tahun 2012 tentang Sistem Peradilan Pidana Anak;

2. Berdasarkan pemeriksaan, motif pelaku memakai narkotika jenis sabu awalnya diajak teman untuk mencoba-coba sehingga pelaku mau memakai sabu, namun menurut hakim pelaku tetap terbukti bersalah melakukan percobaan tindak pidana yang melanggar ketentuan Pasal 53 ayat (1) KUHP;

3. Pelaku dinyatakan bersalah melanggar ketentuan Pasal 127 ayat (1) huruf a Undang-Undang Narkotika, dimana pelaku terbukti sebagai penyalah guna narkotikan golongan I jenis sabu yang digunakan bagi diri sendiri;

4. Menjatuhkan putusan pidana bagi Pelaku meskipun statusnya sebagai anak yaitu berupa Pidana Penjara berdasarkan Pasal 71 ayat (1) huruf e Undang-Undang Nomor 11 Tahun 2012 tentang Sistem Peradilan Pidana Anak.

Padahal dalam kasus WATI SARMILA ALS JESIKA MILA ALS MILA BINTI ARDALIANSYAH perlu dipertimbangkan pula bahwa motif awal pelaku adalah diajak teman sehingga mau mencoba, yang artinya pelaku bukan sebagai pemilik, sehingga pelaku seharusnya direhabilitasi dan dipulihkan kembali pada keadaan semula, bukan dipidana dengan pidana penjara. Sehingga, berdasarkan pertimbangan hakim dalam menjatuhkan Putusan Pidana Nomor 03/Pid.Sus-Anak/2015/PN.Spt, atas nama WATI SARMILA ALS JESIKA MILA ALS MILA BINTI ARDALIANSYAH, Penulis berpendapat bahwa, putusan hakim Pengadilan Negeri Sampit tersebut tidak tepat, karena hakim perlu mempertimbangkan hal-hal lain sebagai berikut:

1. Bahwa kasus-kasus Anak yang tersangkut atau terlibat dengan Hukum yang dibawa ke dalam proses peradilan harus selalu mengutamakan prinsip kepentingan terbaik bagi anak, serta proses penghukuman adalah jalan terakhir (Ultimum Remedium) dengan tetap tidak mengindahkan hak anak, sebagaimana ditegaskan dalam Pasal 71 UU SPPA, bahwa Pidana Penjara berada pada urutan terakhir bentuk penghukuman bagi anak. 
Artinya masih ada upaya lain yang bisa dijatuhkan oleh hakim bagi anak penyalahguna narkotika.

2. Undang-Undang Narkotika lebih mengedepankan penjatuhan sanksi pidana penjara, sehingga menimbulkan permasalahan lain yaitu daya tampung penjara yang saat ini sudah melebihi kapasitas (over crowded). Penjara yang penuh menyebabkan terganggunya kondisi kesehatan bagi warga binaan dan petugas penjara. Selain itu, sesaknya penjara juga berpotensi tingginya konflik di dalam penjara. Lapas dan Rutan per 13 Juli 2020 (Ditjenpas, 2020), dihuni oleh tahanan dan narapidana dengan total 231.978 orang, dari kapasitas Lapas dan Rutan yang hanya 132.107 orang. Artinya terjadi over crowded sebanyak $76 \%$ dari yang selayaknya. Khusus untuk jumlah tahanan dan narapidana yang terjerat kasus tindak pidana narkotika berjumlah 124.618 orang atau $53,72 \%$ dari total penghuni Lapas dan Rutan se Indonesia. Sehingga, separuh lebih dari total penghuni Lembaga Pemasyarakatan saat ini adalah orang yang terlibat dengan kasus tindak pidana narkotika.

Overcrowded merupakan suatu hal yang dialami di dalam Lapas atau Rutan, dimana jumlah penghuni melebihi kapasitas yang berada di Lapas atau Rutan. Penyebab Overcrowded diantaranya:

a. Lebih dari 150 Undang-Undang merekomendasikan pidana penjara.

b. Kebijakan terhadap pecandu atau pemakai narkotika dipidana penjara bukan direhabilitasi.

c. Masih adanya overstaying.

d. Belum sepenuhnya para penegak hukum menerapkan tahanan rumah atau tahanan kota dan lebih cenderung menerapkan tahanan rutan.

e. Belum dimaksimalkannya upaya dalam menerapkan pidana alternatif. Kasus pidana ringan, seperti kasus mencuri sandal, buah, sayur, dan sepatutnya tidak perlu menggunakan hukuman berupa pidana penjara, namun dapat menggunakan alternative hukuman lainnya misalnya pidana bersyarat atau pidana alternatif lainnya (Mujtahid, 2019).

Berdasarkan beberapa hal tersebut, efek hukum pidana penjara yang dijatuhkan pada anak akan memberikan pengaruh yang jauh lebih buruk bagi anak dibandingkan dengan hukuman tindakan.

3. Hakim dapat membuat suatu putusan dengan memperhatikan ketentuan Pasal 103 jo. Pasal 127 ayat (2) UU Narkotika yang menyatakan bahwa hakim dapat memutus untuk memerintahkan yang bersangkutan menjalani pengobatan dan/atau perawatan melalui rehabilitasi jika pecandu narkotika tersebut terbukti bersalah melakukan tindak pidana Narkotika. Upaya rehabilitasi merupakan salah satu bentuk perlindungan khusus yang diberikan kepada anak oleh negara sebagaimana diatur dalam Undang-Undang Nomor 35 Tahun 2014 tentang Perubahan Atas Undang-Undang Nomor 23 Tahun 2002 tentang Perlindungan Anak, dimana dalam Pasal 67 menyatakan bahwa:
"Perlindungan khusus bagi anak yang menjadi korban penyalahgunaan narkotika, alkohol, psikotropika dan zat adiktif lainnya dan anak yang terlibat dalam produksi dan distribusinya dilakukan melalui upaya pengawasan, pencegahan, rehabilitasi".

Sehingga, pertimbangan hakim dalam menjatuhkan putusan terhadap anak yang sudah kawin sebagai subyek yang tersangkut dengan hukum berdasarkan putusan Pengadilan Negeri Sampit Nomor 03/Pid.Sus-Anak/2015/ PN.Spt haruslah memperhatikan mental dan psikologis anak terlebih lagi terkait dengan kasus narkotika, dibandingkan dengan menjatuhkan vonis berupa putusan pidana penjara akan lebih bijak apabila anak tersebut direhabilitasi dan dipulihkan.

\section{PENUTUP}

\subsection{Kesimpulan}

Adapun yang menjadi kesimpulan dalam Penulisan ini sesuai dengan permasalahan yang diangkat oleh Penulis yaitu:

1. Pengaturan anak yang sudah kawin sebagai subyek yang berhadapan dengan hukum, mengacu pada asas lex specialis derogat lex generalis yaitu pengaturan yang digunakan sesuai dengan aturan yang mengatur secara khusus mengenai anak, dalam hal ini mengacu pada Undang-Undang Nomor 23 Tahun 2002 tentang Perlindungan Anak dan Undang-Undang Nomor 11 Tahun 2012 tentang Sistem Peradilan Pidana Anak, yang menyatakan bahwa anak merupakan seseorang yang belum berusia 18 tahun, dan juga anak yang masih dalam kandungan, tanpa terkecuali apakah sudah kawin atau belum.

2. Pertimbangan hakim dalam Putusan Pengadilan Negeri Sampit Nomor:03/Pid.Sus-Anak/2015/PN.Spt, tidak tepat karena meskpiun terpidana adalah anak yang sudah kawin namun tetap saja terpidana masih dikategorikan sebagai anak berdasarkan asas lex specialis derogat lex generalis, sehingga penjatuhan hukuman berupa rehabilitasi lebih tepat dibandingkan pidana penjara, selain itu pula tujuan akhir dari sistem peradilan pidana anak lebih menitikberatkan pada Keadilan Restoratif (Restorative Justice) yaitu upaya menyelesaikan suatu perkara dengan berorientasi pada pemulihan kembali ke keadaan semula, serta bukan upaya pembalasan.

\subsection{Saran dan Rekomendasi}

1. Hendaknya Pembuat Kebijakan (Pemerintah) membuat aturan khusus yang mengatur pembedaan mengenai batasan usia anak dari sisi tindak pidana dan kategori dewasa dari sisi keperdataan, agar tidak menimbulkan inkonsistensi diantara hakim, sehingga tidak ada lagi perbedaan penafsiran dalam menentukan batas usia 
anak atau dewasa, yang akan menjadi acuan dan landasan bagi para hakim dalam membuat pertimbangan hukum suatu putusan terkait dengan anak yang sudah kawin sebagai subyek yang berhadapan dengan hukum.

2. Hendaknya Hakim dalam mengambil setiap keputusan, perlu memperhatikan hak-hak anak dengan menjaga harkat dan martabat seorang anak, yang pada dasarnya perlu dilindungi, terlebih lagi anak sebagai penyalahguna narkotika, hakim harusnya memperhatikan mental dan psikologis anak, dibandingkan dengan menjatuhkan vonis berupa putusan pidana penjara akan lebih bijak apabila anak tersebut direhabilitasi dan dipulihkan.

\section{DAFTAR PUSTAKA}

Al Bukhori, J., 2009. Sekuntum Mawar Untuk Remaja, Peran Islam Untuk Pergaulan. Pustaka Al Mawardi, Jakarta.

Andrianih, A. 2014. Anak Sebagai Subjek Khusus dalam Hukum. Diakses dari: http://www.gresnews.com/berita/ opini/91081--anak-sebagai-subjek-khusus-dalamhukum/ (13 Juli 2020).

Anggara, E.A. and Napitulu, A.A.H., 2016. Studi Implementasi Penanganan Anak di Pengadilan Berdasarkan UU SPPA. Institute for Criminal Justice Reform, Jakarta Selatan.

Astuti, M.S., 1997. Pemidanaan terhadap Anak Sebagai Pelaku Tindak Pidana. Malang, IKIP Malang.

Ditjenpas. 2020. Sistem Database Pemasyarakatan. Diakses daeri: http://smslap.ditjenpas.go.id/admin/top/top30/ daily (13 Juli 2020).

Hukum Online. 2016. Dilema Anak Berhadapan Hukum dengan Penerapan UU SPPA. Diakses dari: https:// www.hukumonline.com/berita/baca/lt579220ac6fafc/ dilema-anak-berhadapan-hukum-dengan-penerapanuu-sppa/ (11 April 2020).

Manan, B., 2004. Hukum Positif Indonesia: Satu Kajian Teoritik. FH UII Press.

Mujatahid, H. 2019. Penyebab Overcrowded Lapas di Indonesia. Diakses dari: https://www.kompasiana.com/ halim88088/5ce4c2463ba7f717fe7b5115/over-crowded -lapas-rutan-di-indonesia-apa-saja-sihpenyebabnya\#: :text=Overcrowded $\% 20$ merupakan $\%$ 20suatu $\% 20$ hal\%20yang,berada\%20di\%20dalam\%
20Lapas\%2FRutan.\&text=Belum\%20optimalnya\% 20penegak\%20hukum\%20menerapkan,Belum\% 20optimalnya\%20penerapan\%20pidana\%20alternatif (14 Juli 2020).

Muljono, E.L., 1998. Kumpulan Peraturan Perundangundangan Tentang Perlindungan Anak. Harvarindo, Jakarta.

Pramesti, T. J. A. 2016. Hukuman Bagi Anak di Bawah Umur Pengguna Sabu. Diakses dari: https:// www.hukumonline.com/klinik/detail/ulasan/ It56964786cc7fc/hukuman-bagi-anak-di-bawah-umurpengguna-sabu/ (11 April 2020).

Prinst, D., 1997. Hukum Anak Indonesia. Citra Aditya Bakti.

Satrio, J., 1999. Hukum Pribadi Bagian I Persoon Alamiah, Bandung. Citra Aditya Bakti.

Soekanto, S. and Mamudji, S., 2014. Penelitian Hukum Normatif Suatu Tinjauan Singkat. Cet. 16. Rajawali Pers, Jakarta.

Yuliandri, 2009. Asas-asas Pembentukan Peraturan Perundang-Undangan yang Baik: Gagasan Pembentukan Undang-Undang Berkelanjutan. Raja Grafindo Persada.

\section{Peraturan Perundangan-Undangan}

Undang-Undang Dasar Negara Republik Indonesia Tahun 1945.

Kitab Undang-Undang Hukum Perdata.

Kitab Undang-Undang Hukum Pidana.

Undang-Undang Nomor 1 Tahun 1974 tentang Perkawinan Undang-Undang Nomor 39 Tahun 1999 tentang Hak Asasi Manusia.

Undang-Undang Nomor 23 Tahun 2002 tentang Perlindungan Anak sebagaimana telah diubah beberapa kali terakhir dengan Undang-Undang Nomor 17 Tahun 2016 tentang Penetapan Peraturan Pemerintah Pengganti Undang-Undang Nomor 1 Tahun 2016 tentang Perubahan Kedua Atas UndangUndang Nomor 23 Tahun 2002 tentang Perlindungan Anak Menjadi Undang-Undang.

Undang-Undang Nomor 35 Tahun 2009 tentang Narkotika Undang-Undang Nomor 11 Tahun 2012 tentang Sistem Peradilan Pidana Anak.

Putusan Pengadilan Negeri Sampit Nomor:03/Pid.SusAnak/2015/PN.Spt.

Putusan Pengadilan Negeri Sampang Nomor Putusan 125/ Pid.B/2015/PN. 